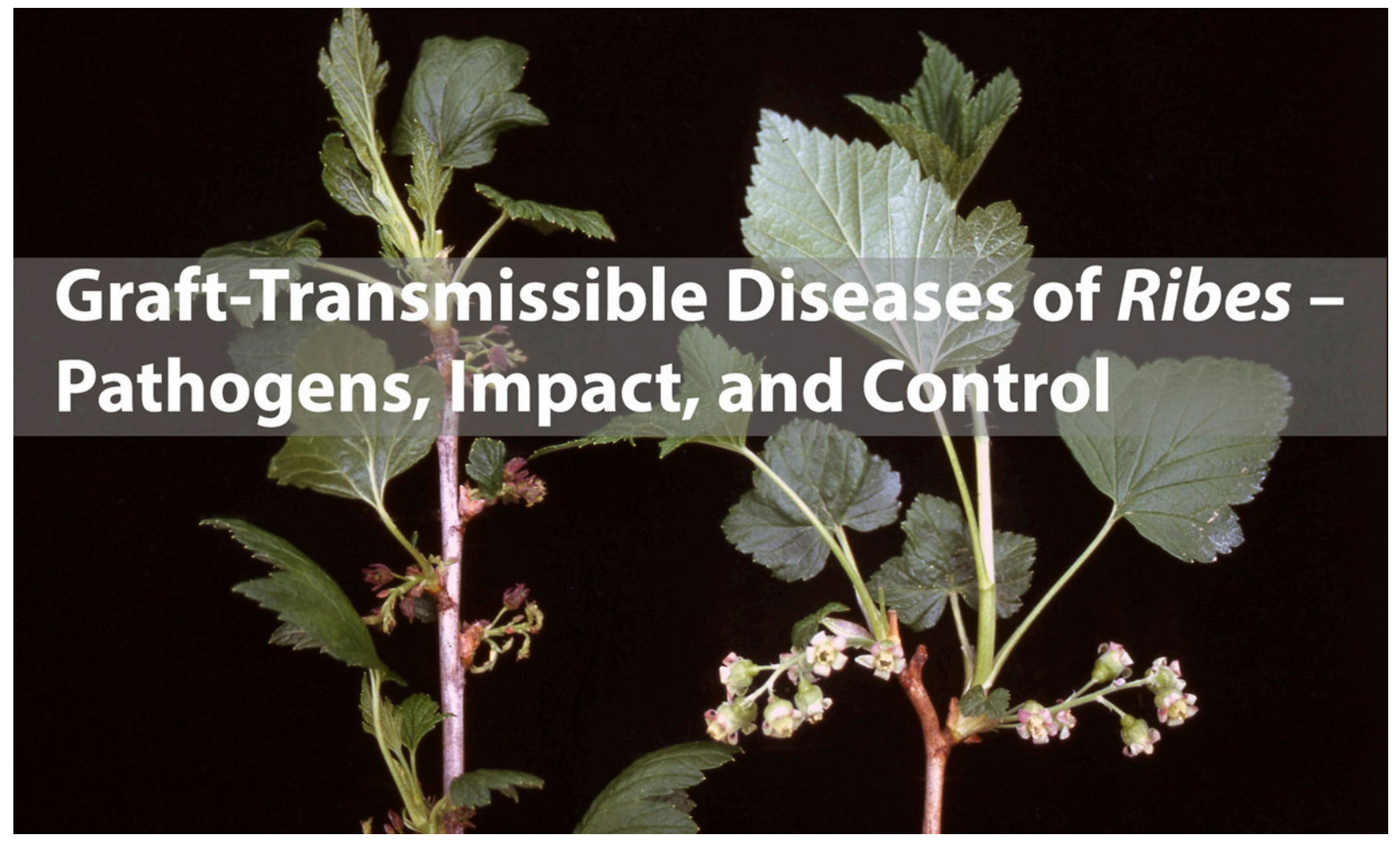

\title{
Josef Špak, ${ }^{1, \dagger}$ Igor Koloniuk, ${ }^{1}$ and loannis E. Tzanetakis ${ }^{2}$
}

${ }^{1}$ Biology Centre, Czech Academy of Sciences, 37005 České Budějovice, Czech Republic

${ }^{2}$ Department of Entomology and Plant Pathology, Division of Agriculture, University of Arkansas System, Fayetteville, AR 72701, U.S.A.

Keywords: blackcurrant, red currant, virus, phytoplasma, disease, symptoms, vector, aphid, mite, detection, elimination, yield reduction, protection

There are more than 150 species in the genus Ribes (Barney and Hummer 2005), yet only two species have primarily been used for the development of commercially relevant cultivars: Ribes nigrum (blackcurrant) and R. rubrum (red currant). Their fruit is consumed raw or processed as juice, jam, purée, jelly, liqueur, "cassis wine," and for imparting color and flavor to dairy products. In addition, currants are increasingly recognized as rich sources of vitamin $C$ and have beneficial effects on several human diseases such as hypertension, osteoporosis, inflammation, cancer, and cardiovascular disease (Brennan et al. 2007). Efforts are being made to enhance some of the valued compounds present in currants as well as yield, fruit size, resistance to pests and diseases, uniform ripening, and suitability for mechanical harvesting.

Currants are widely cultivated in more than 30 countries across temperate zones of Europe, Asia, South America, Australia, and New Zealand. About $99 \%$ of the world's production comes from Europe, mainly the Russian Federation, Poland, Ukraine, Germany,

${ }^{\dagger}$ Corresponding author: J. Špak; spak@umbr.cas.cz

Funding: This research has received institutional support from the Czech Academy of Sciences RVO 60077344 and the U.S. Department of Agriculture award 14-8130-0420-CA.

The author(s) declare no conflict of interest.

Accepted for publication 28 August 2020.

This article is in the public domain and not copyrightable. It may be freely reprinted with customary crediting of the source. The American Phytopathological Society, 2021 the Netherlands, and France. Currant cultivation is particularly popular in home gardens in Central and Eastern Europe for fresh fruit, juice, or as component of desserts. In 2018, the total world acreage of black and red currant exceeded 120,000 ha, yielding more than 650,000 tons and producer prices ranged from 0.13 to 5.75 EUR/ $\mathrm{kg}$ in 2018 (FAOSTAT 2020). Production data for red currant are not available even though in some countries, e.g., Germany and the Czech Republic, red currant cultivation is prevalent over that of blackcurrant. According to the International Blackcurrant Association (2019), organic production of blackcurrant is increasing, constituting $\sim 2 \%$ of the total production (2018 statistics; FAOSTAT 2020 ) with an average producer price of $0.72 \mathrm{EUR} / \mathrm{kg}$.

This article provides an up-to-date review of pathogenic Ribes viruses and phytoplasmas including symptoms, transmission, detection, economic impact, and control measures. Viruses that are only reported as sequences without data on their biological significance or have only been reported in non-peer-reviewed publications (e.g., meeting abstracts or proceedings) will not be addressed here. The same goes for agents for which a type isolate is lacking and no genomic information is available, making it impossible to determine whether a new discovery is an isolate of a previously described agent or a new virus altogether. No viroids have been reported in $R i$ bes to date (EFSA PLH Panel 2019).

\section{Diagnostics}

Ribes-infecting viruses and phytoplasmas are recalcitrant for diagnosis. They are difficult to transmit by grafting or mechanical means to herbaceous indicator plants because of their low concentration and uneven distribution (Dolan et al. 2011). Some currant virus vectors such as eriophyid mites and nematodes are difficult to study, posing obstacles in detection and identification of diseasecausing agents for decades. 
New diagnostic methods have greatly advanced the field. The identification of blackcurrant reversion virus (BRV), the putative causal agent of the most important disease in Ribes blackcurrant reversion, is an excellent example. The disease symptoms were described by Ritzema Bos (1904), but the virus was not characterized until the 1990s (Lemmetty et al. 1997), despite significant efforts over the years. BRV transmission to herbaceous hosts, purification, preparation of antibodies, and genome sequencing enabled the design of sensitive detection tests (Lemmetty et al. 1997; Lemmetty and Lehto 1999).

The employment of enzyme-linked immunosorbent assay (ELISA) and reverse transcription (RT)-PCR substantially improved routine detection of viruses in planting material in the 1980s and 1990s. Furthermore, advances in high-throughput sequencing (HTS) (Ho and Tzanetakis 2014; Koloniuk et al. 2018) opened a new era, deciphering virus variants and mixed infections, and led to the characterization of several new viruses in Ribes. HTS contributed to the molecular characterization of viruses that had been observed decades ago by electron microscopy, e.g., a rhabdo- and a closterovirus (Roberts and Jones 1997). The impact of HTS use is immense: seven viruses and numerous diseases were described in the handbook on virus diseases of small fruits by Converse (1987) and 11 were reviewed by Martin and Tzanetakis (2015). A few years later, there are at least 21 documented viruses infecting currants.

\section{Virus Descriptions}

Blackcurrant reversion virus (Nepovirus, BRV) is the putative causal agent of the homonymous disease. The name reflects the change of plant growth habit from the cultivated form toward the wild type of blackcurrant. There is strong documentation of two forms (strains) that differ in pathogenesis; a common (European, E) and a severe $(\mathrm{R})$, present in Scandinavia, Central Europe, and countries of the former Soviet Union. Leaves of susceptible blackcurrant cultivars decrease in number and size. Marginal serrations and the number of main veins are affected, and leaves display less defined sinuses at the petiole. In addition, the $\mathrm{R}$ form increases flower pigmentation and induces division of the petals (Fig. 1). Stamens are usually absent and the style elongates (Adams and Thresh 1987a; Jones 2002). To date, there are no available tools other than symptomology to distinguish between the two forms. When infected with either E or R forms, reversion-affected flowers are usually sterile, causing substantial losses in production (Adams and Thresh 1987c). Red currants are not affected to the same degree. After infection, symptom development takes 2 to 3 years and affects only a few branches. It may take several more years before the whole plant shows symptoms (Adams and Thresh 1987c). The infected plants become unproductive.

Gooseberry vein-banding associated virus (Badnavirus, GVBaV) is the putative causal agent of the homonymous disease (Petrzik et al. 2012). Gooseberry vein-banding disease affects blackcurrant, red currant, and gooseberry, and all commercial as well as other Ribes species (Adams and Posnette 1987; Jones 2002). Symptoms in blackcurrant and red currant are less obvious than those observed in gooseberry. The disease is characterized by a chlorosis of the lamina adjacent to the main veins of leaves (Fig. 6). Often symptoms occur only in a sector of the leaf and are much less pronounced and more transient in occurrence in blackcurrant and red currant than in gooseberry (Adams and Posnette 1987). GVBaV is transmitted in a semipersistent manner by several aphid species (Aphis grossulariae, Nasonovia ribisnigri, and Hyperomyzus spp.) and experimentally by grafting (Adams and Posnette 1987).

Arabis mosaic virus (Nepovirus, ArMV), Raspberry ringspot virus (Nepovirus, RpRSV), Strawberry latent ringspot virus (Sadwavirus, SLRV), Tomato black ring virus (Nepovirus, TBRV), Tomato ringspot virus (Nepovirus, ToRSV), Cherry leaf roll virus (Nepovirus, CLRV), and Tobacco rattle virus (Tobravirus, TRV) are nematodetransmitted viruses known to infect Ribes species. Nepoviruses are transmitted by species in the genera Xiphinema, Longidorus, and Paralongidorus, although a nematode vector for CLRV is yet to be identified (Brown et al. 1996; Jones et al. 1994), whereas TRV is transmitted by several species in the genera Trichodorus and Paratrichodorus (Ploeg et al. 1992). All nematode-transmitted viruses are persistent in their vectors (Brown et al. 1995). Another mode of transmission of the group is through pollen and seed. Given the wide host range, pollen could be a major mode of dissemination, as several common weeds in Ribes fields could be asymptomatic carriers of the viruses. The effects of the nematode-transmitted viruses, as is the case with many of the viruses infecting Ribes, depend on genotype, plant age, and virus strain. For example, ArMV is asymptomatic in gooseberry and red currants but causes severe symptoms in blackcurrants (Jones and McGavin 1996), whereas TRV incidence in Ribes is low and has only been shown to infect red currant (van der Meer 1987). CLRV has only been recorded to infect red currant in New Zealand, inducing pale green mottling on spring growth (Lebas et al. 2016). In general terms, nepovirus-associated symptoms in susceptible genotypes include yellowing, mosaic, ringspots, oak leaf patterns, plant epinasty, and decline (Converse 1987).

Cucumber mosaic virus (Cucumovirus, CMV) can infect a large number of woody and herbaceous plant species worldwide (Bremer 1983; Converse 1987; Musil et al. 1979; van der Meer 1987). It causes green mottle disease or leaf pattern in black and red currant (Adams and Thresh 1987b) and is transmitted either mechanically or via grafting, dodder, or a plethora of aphids. CMV is considered a rather common virus in Ribes, although this has not been verified by extensive surveys in the field.

Alfalfa mosaic virus (Alfamovirus, AMV) was detected in a plant of blackcurrant with interveinal white mosaic disease (Jones and McGavin 1996) in the United Kingdom. Mechanical AMV inoculation of blackcurrant confirmed its causative role in the disease. The virus is known to be transmitted mechanically and by pollen, seeds, and aphids.

Blackcurrant leafroll-associated virus 1 (Closterovirus, BCLRaV1) was identified in blackcurrant in 2010 and later in red currant (Besse et al. 2010). Recently, it was reported from the U.S.A. and several European countries (Koloniuk et al. 2018; Zheng et al. 2018). Leafroll or yellow line pattern symptoms were observed in some virus-positive plants, whereas others did not show any symptoms. There is no identified vector or mode of transmission. The high variability of genomic sequences of BcLRaV-1 (Koloniuk et al. 2018) might complicate development of a reliable detection method.

Currant latent virus (Cheravirus, CuLV) was reported in 2015 in Europe (Petrzik et al. 2015) but has also been detected in the United States (Ho et al. 2016). Symptomless infection was observed in black, red, and white currant (Petrzik et al. 2015). Although infected plants were colonized with the red currant aphid, Cryptomyzus ribis, it was not confirmed as the virus vector. Other known cheraviruses are pollen or seed transmitted and have a narrow host range.

Sowbane mosaic virus (Sobemovirus, SoMV; syn. Rubus chlorotic mottle virus, RuCMV) causes symptoms of leaf curling in

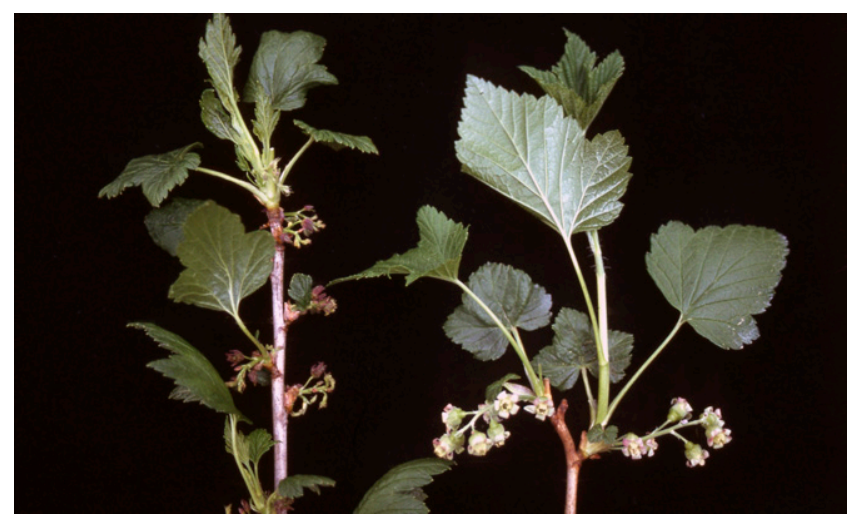

Fig. 1. Symptoms of the R-form of blackcurrant reversion disease (left) in blackcurrant cv. Karlštejnský dlouhohrozen and healthy plant (right). Severely malformed, dark, sterile flowers contrast with healthy flowers exhibiting fully developed stamens. 
red currant (McGavin and MacFarlane 2009). It infects a number of woody and herbaceous plant species, often in a symptomless manner. There is little information available on its impacts on Ribes plants (Besse et al. 2010). The virus has been known since 1958 (Tremaine and Hamilton 1983) and its transmission occurs through pollen and seed.

\section{Viruses of Unknown Distribution}

Actinidia virus $\mathrm{X}$ (Potexvirus, AVX) was first described infecting Actinidia chinensis (Pearson et al. 2011). The single report of the virus in Ribes comes from an interception of symptomatic blackcurrant plants (cv. Baldwin) entering Canada (James and Phelan 2016). Symptoms include leaf chlorosis and deformation. The virus belongs to the genus Potexvirus and is the only known virus of this genus infecting Ribes. The main means of spread is through mechanical transmission, a property verified in two separate studies (James and Phelan 2016; Pearson et al. 2011).

Blackcurrant-associated rhabdovirus (Nucleorhabdovirus, BCaRV) was identified from a single asymptomatic blackcurrant plant in the U.S.A. in 2018 (Wu et al. 2018) (Figs. 7 and 8). The distribution of the virus, its vectors, and its impact on the host are unknown.

Blackcurrant leaf chlorosis associated virus (Idaeovirus, BCLCaV; syn. Blackcurrant idaeovirus) was reported simultaneously in Canada and the United States in symptomatic blackcurrant cultivars (James

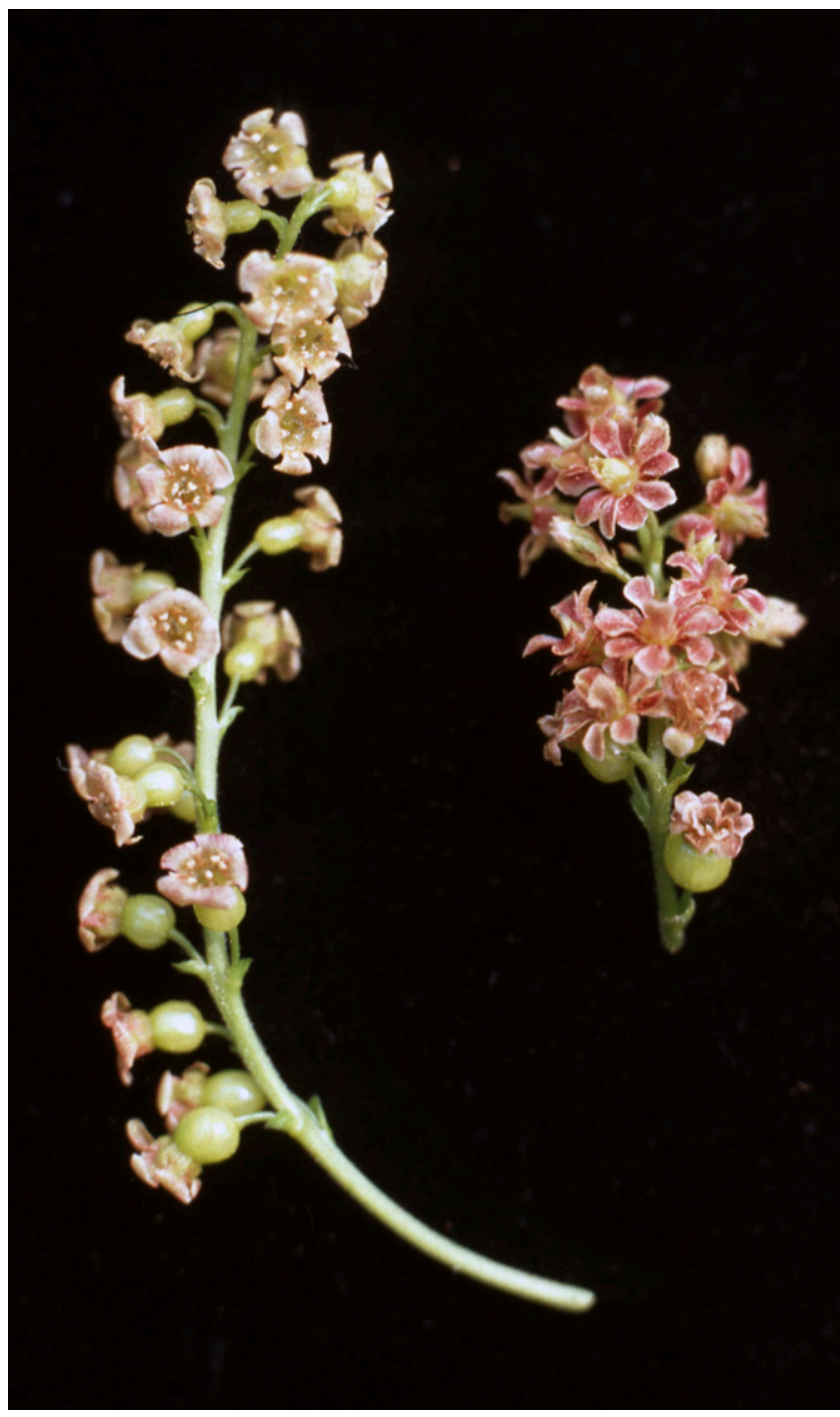

Fig. 2. Shortened raceme of red currant cv. Vitan affected with full blossom disease (right) compared with a healthy one (left). and Phelan 2017; Thekke-Veetil et al. 2017). The virus belongs to the genus Idaeovirus, with members that are efficiently transmitted by seed and pollen. The virus has been associated with leaf chlorosis (Thekke-Veetil et al. 2017), but this needs to be further investigated.

Blackcurrant waikavirus A (Waikavirus, BCWA) is a virus first discovered in the early 2010s (Ho and Tzanetakis 2014) and only recently characterized (Thekke-Veetil et al. 2020). This typical waikavirus was first found in a $R$. americanum cv. 'Gall' plant that originated in South Dakota and displayed virus-like symptoms. The assayed plants were coinfected with blackcurrant leaf chlorosis associated virus and therefore symptoms cannot be attributed

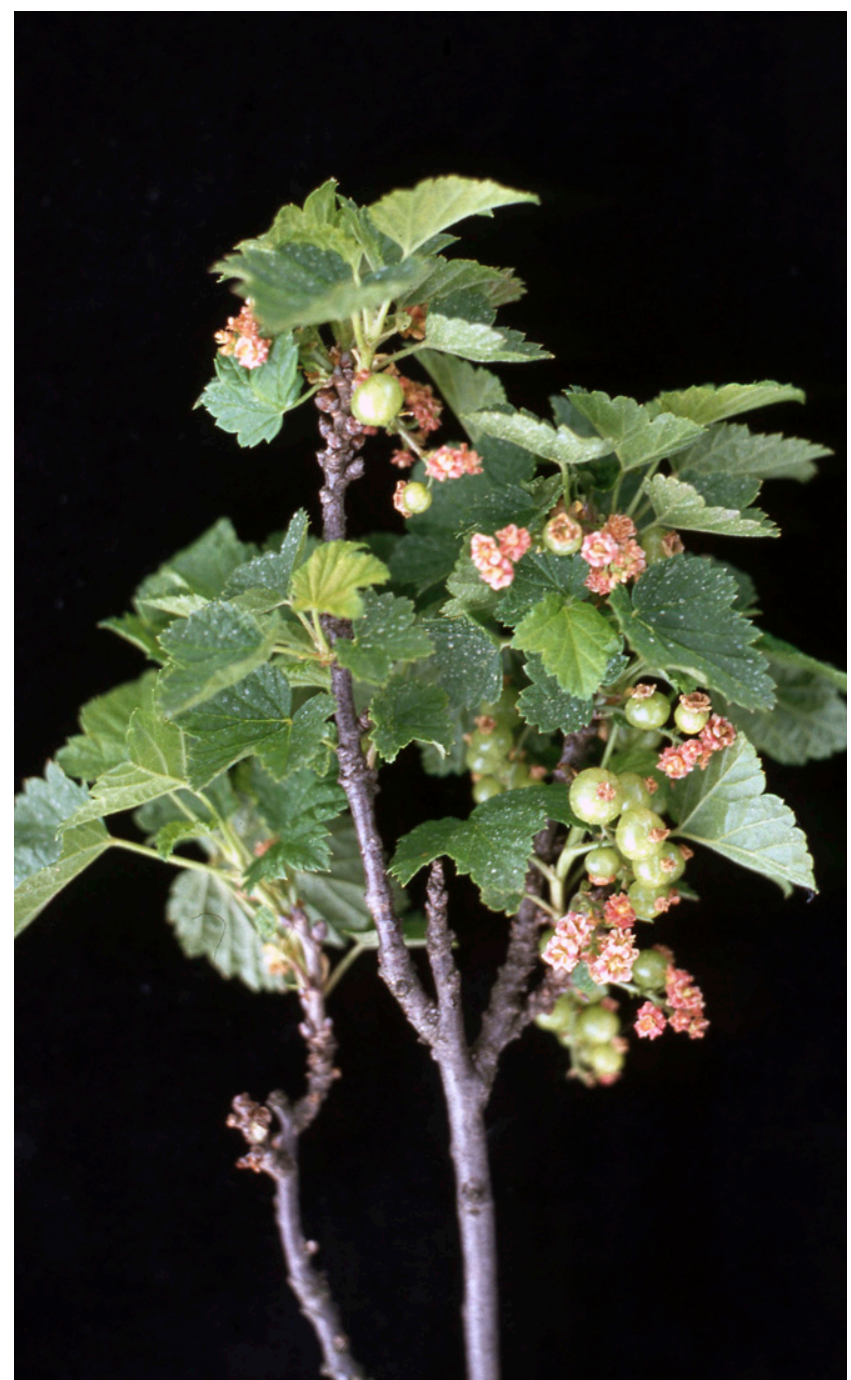

Fig. 3. Typical symptoms of full blossom disease in red currant cv. Vitan with ripening fruits and persistent sterile malformed flowers.

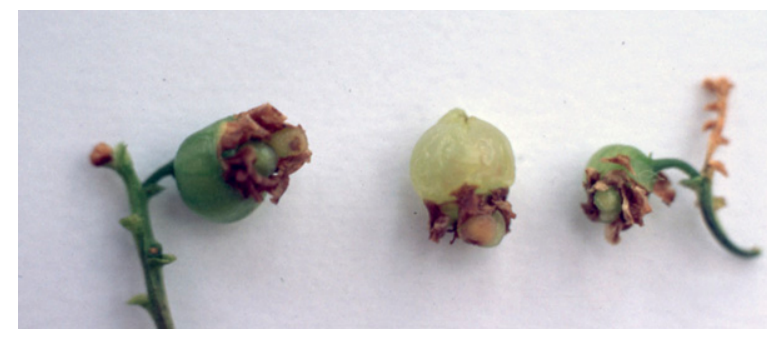

Fig. 4. Deformation of fruit in red currant affected by full blossom disease. 
specifically to either of the viruses. The prevalence of the virus in currant-growing areas is unknown. Because of the taxonomic placement of this virus, the vector is speculated to be an aphid.

Currant virus A (Capillovirus, CuVA) was found in a red currant plant that was coinfected with currant latent virus in the Czech Republic. There is little information on its transmission and impacts on Ribes plants. Other known capilloviruses are transmitted by either seed or grafting (Petrzik et al. 2016).

Ribes americanum virus A (Betaflexiviridae, RAVA) was detected in the same $R$. americanum cv. 'Gall' as BCWA. There is no significant epidemiological or other information on the virus other than its unique phylogenetic placement as the type member of a monotypic genus in the family Betaflexiviridae. The unique placement of RAVA makes it difficult to speculate on its mode of transmission (Thekke-Veetil et al. 2018).

\section{Phytoplasmas}

Candidatus (Ca.) Phytoplasma species, phytopathogenic mollicutes, originally defined as Mycoplasma-like organisms (MLOs), were associated with full blossom disease (FBD) (Fig. 2) of red currant, first described in the former Czechoslovakia by Rakús (1971) and later observed in Poland, Hungary, and Germany. Association

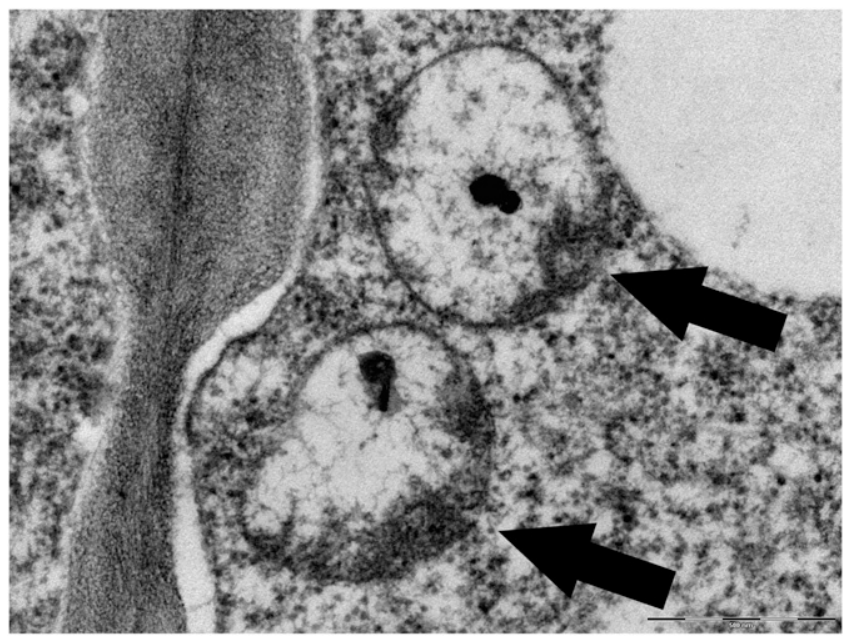

Fig. 5. Detail of Candidatus Phytoplasma asteris bodies in a cell from phloem tissue of a fruit stalk of red currant $\mathrm{cv}$. Vitan infected with full blossom disease showing ribosomes and fine fibrillary DNA. Bar represents $500 \mathrm{~nm}$.

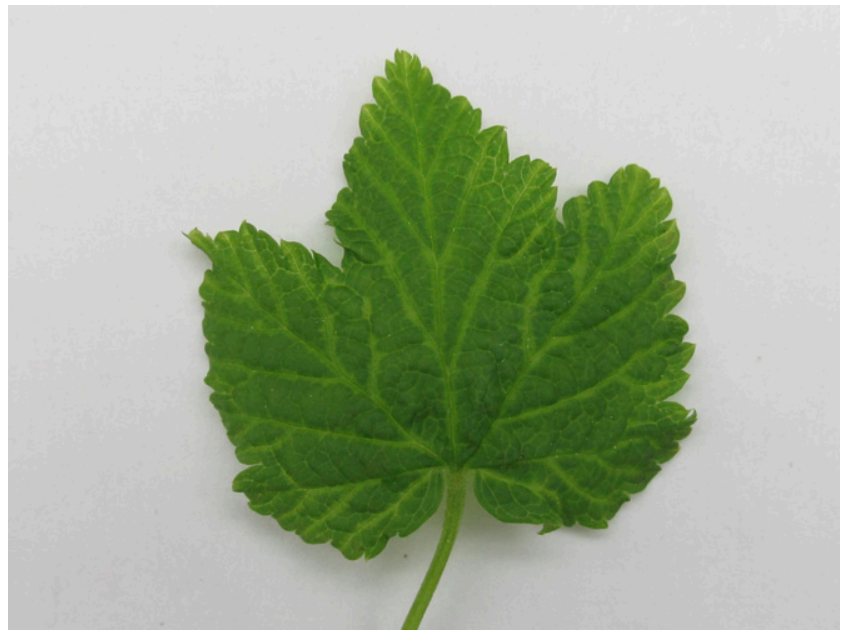

Fig. 6. Vein banding symptoms in red currant infected with Gooseberry vein banding associated virus. of FBD with phytoplasmas was hypothesized by Rakús et al. (1974) because of the presence of pleomorphic bodies in the phloem of symptomatic racemes observed by electron microscopy. Typical FBD symptoms include elongated style, absence of stamens, and superior ovaries. Petals and sepals change color and may enlarge, multiply, and become leaf-like. Two characteristic features of the disease are the persistence of sterile flowers (Fig. 3) and production of malformed fruit with extruding seeds (Fig. 4). Plants are stunted and produce sparse crops of small berries.

Špak et al. (2009) identified $\mathrm{Ca}$. Phytoplasma asteris, 16SrI-C (Fig. 5), 16SrI-B, Ca. Phytoplasma mali, 16SrX-A, Ca. Phytoplasma prunorum, $16 \mathrm{SrX}-\mathrm{B}, \mathrm{Ca}$. Phytoplasma pyri, $16 \mathrm{SrX}-\mathrm{C}$ in infected blackcurrants with reversion symptoms, and red and white currants with FBD symptoms. However, symptoms of plants infected solely by BRV or those infected with both BRV and phytoplasmas were identical. Moreover, scions of periwinkle infected with aster yellows phytoplasmas of subgroup $16 \mathrm{SrI}-\mathrm{C}$ and $16 \mathrm{SrI}-\mathrm{B}$, grafted onto seedlings of red and blackcurrant, resulted in symptomless infection in red currant. They concluded that FBD symptoms are induced by BRV rather than a phytoplasma. Phytoplasmas are spread by insects of the families Cicadellidae (leafhoppers), Fulgoridae (planthoppers), and Psyllidae (jumping plant lice), which feed on the phloem of infected plants. However, there are no data on vector transmission of phytoplasmas to currants.

\section{Economic Impact and Occurrence of Graft Transmissible Diseases of Ribes}

$\mathrm{BRV}, \mathrm{GVBaV}, \mathrm{CMV}$, and the nepoviruses are subject to testing during the production of Ribes nuclear stock in Europe. Those viruses, together with several other virus-like pathogens or diseases of unknown importance, are part of the European Plant Protection

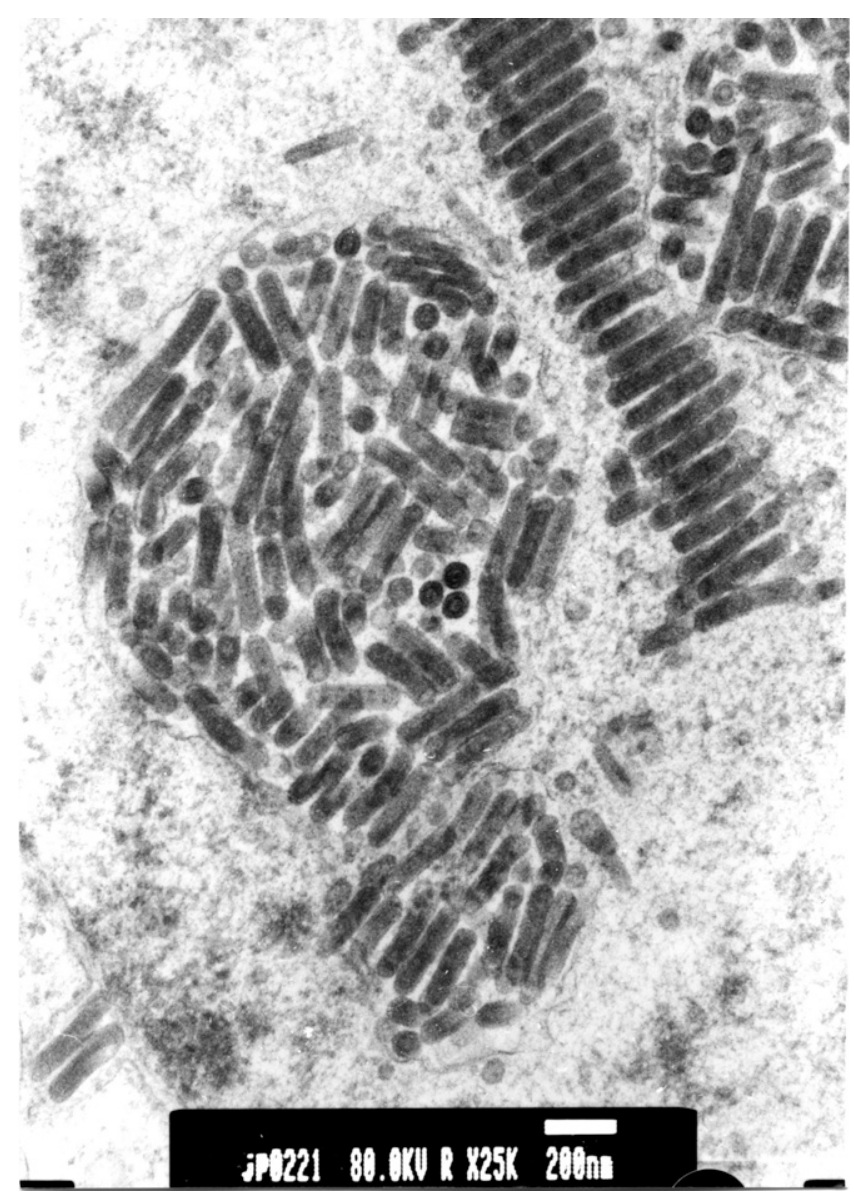

Fig. 7. Rhabdovirus-like particles forming dispersed rafts in the nucleus of blackcurrant parenchyma cell. Bar represents $200 \mathrm{~nm}$. 
Organization (EPPO) certification scheme for Ribes (Anonymous 2008). There is no tolerance for any virus or virus-like agent in generation 1 (G1 or nuclear stock) (Anonymous 2017). There is some tolerance allowed in G2 and G3 (0.05\% infection), whereas the final product that reaches the growers (G4 or certified material) tolerates infections up to $0.5 \%$.

Blackcurrant reversion disease associated with BRV has been reported to cause major losses in some cultivars of currants from all countries where blackcurrant is grown commercially, with the exception of the Americas (Adams and Thresh 1987a). Differences between host genotypes in sensitivity to the disease have been observed. For instance, cv. Ben Lomond is more susceptible than cv. Titania. Yield can decrease drastically; reduction after a 4-year trial was reported to be as much as $50 \%$ and after 6 years about $75 \%$ for Ben Lomond (Pluta and Zurawicz 1999). In New Zealand, reversion has had a devastating effect on blackcurrant, forcing many growers to stop growing the crop altogether (Wood and Langford 1998). Full blossom disease can reduce yield by $70 \%$ in some cultivars (Špak et al. 2006). Furthermore, the gall mite, the putative vector of the virus causing FBD, is itself damaging on blackcurrant, causing galling and bud sterility (Adams and Thresh 1987a).

GVBaV occurs commonly in Ribes species worldwide and, under experimental conditions, is known to decrease growth and yield in gooseberry and red currant by $15 \%$ (Adams and Posnette 1987). No data are available for effects in blackcurrant, but effects on growth and yield are likely.

The regional occurrence of Ribes-infecting viruses has been summarized by Martin and Tzanetakis (2015) with BRV, GVBaV, and nematode-transmitted viruses being widely distributed in Europe and New Zealand. Ribes germplasm collections provide an invaluable source for future studies. Indeed, most of the new viruses have been found in accessions from germplasm collections (ThekkeVeetil et al. 2017, 2018, 2020; Wu et al. 2018; Zheng et al. 2018). This makes the relevance of the viruses' geographic origin and occurrence in Ribes field uncertain. Similarly, descriptions and specificity of symptoms induced by the newly described viruses should be read critically given that several have originated from shrubs with mixed infections (Zheng et al. 2018). Symptoms, occurrence, population structure, vectors, epidemiology, and effects on quality and yield of newly described viruses must be explored in depth given the significant knowledge gaps that impede the development of sustainable control measures. For example, elucidating vectors and transmission modes would allow for evidence-based control strategies. Only after such data become available can we evaluate the relevance of new virus discoveries in Ribes diseases and determine priority targets for testing and virus elimination from propagation materials.

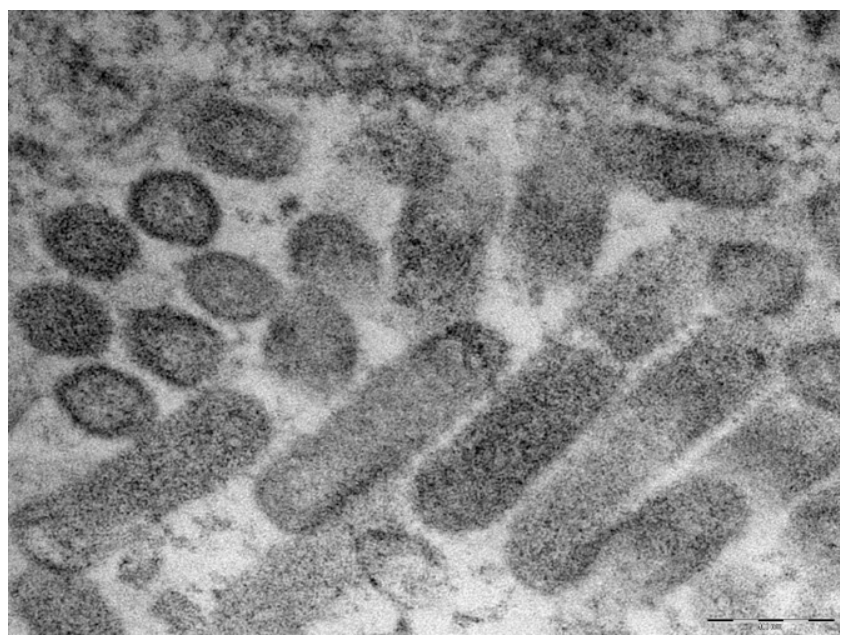

Fig. 8. A detail of rhabdovirus-like particles in blackcurrant cv. Titania. Bar represents $100 \mathrm{~nm}$.

\section{Control}

Prevention measures are basic for control of Ribes virus diseases. Nematode-transmitted viruses are an excellent example. A primary concern for producers during the latter part of the 20th century has decreased in importance with the use of certified propagation materials (Anonymous 2008). Notwithstanding, strict control of viruses and vectors remains important in countries that lack comprehensive certifications systems (Valasevich and Kolbanova 2010). Best management practices are important to minimize the introduction and spread of viruses; for example, establishment of new fields in areas where other berries and fruit trees were recently grown should be avoided given the shared virome between those crops and Ribes. In Europe, testing for nematode vectors (Longidorus and Xiphinema) is now required before establishment of new fields and propagation of G1 material (Anonymous 2017).

In the field, control of reversion disease and gall mite is primarily based on virus-tested, certified material, focusing on eliminating infection foci by roguing out affected plants. Application of acaricides (e.g., endosulfan) during the main mite dispersal period is banned in most countries because of their impact on the environment and food safety (Jones 2002). A single galled bud (Fig. 9) may contain up to 35,000 mites and an infested bush often has $>100$ galls (Adams and Thresh 1987a). It is generally agreed that once reversion infection and/or gall mite infestation reaches $>5 \%$ incidence in crops, there is no economically feasible strategy to control the virus (Adams and Thresh 1987c). To minimize the risk of infection, crops need to be grown at considerable distances from mite-infested material. With the increase of organic production, nonsynthetic chemical methods have become available. Nielsen et al. (2013) reported a novel machine vision-based approach for detecting and mapping gall mite infection in dormant buds on blackcurrant bushes. Using artificial intelligence and deep learning scouting, a vehicle fitted with cameras achieved the same precision as human inspection, minimizing labor costs. Pedersen et al. (2006) described elimination of $C$. ribis by dipping hardwood cuttings of cv. Ben Adler in water at $45^{\circ} \mathrm{C}$ for $10 \mathrm{~min}$. Hot water-treated cuttings had better survival and growth than nontreated cuttings. The method was adopted by producers using simple homemade thermostat-equipped baths.

Susceptibility to BRV and the gall mite, and the challenges in controlling them, have made breeding for resistance a priority in blackcurrant breeding programs (Pluta 2012). The first linkage map of blackcurrant was published (Brennan et al. 2007), and a PCR-based marker linked to gall mite resistance has been deployed in the selection of resistant germplasm (Brennan et al. 2008). The $\mathrm{Ce}$ gene from gooseberry has been introduced into blackcurrant to confer gall mite resistance. The use of $\mathrm{Ce}$ cultivars that confer resistance to viruliferous $C$. ribis and $C$. spicata and consequently to BRV appears to be effective. In Scotland, the James Hutton Institute has active commercial breeding programs for blackcurrant and has produced the 'Ben'

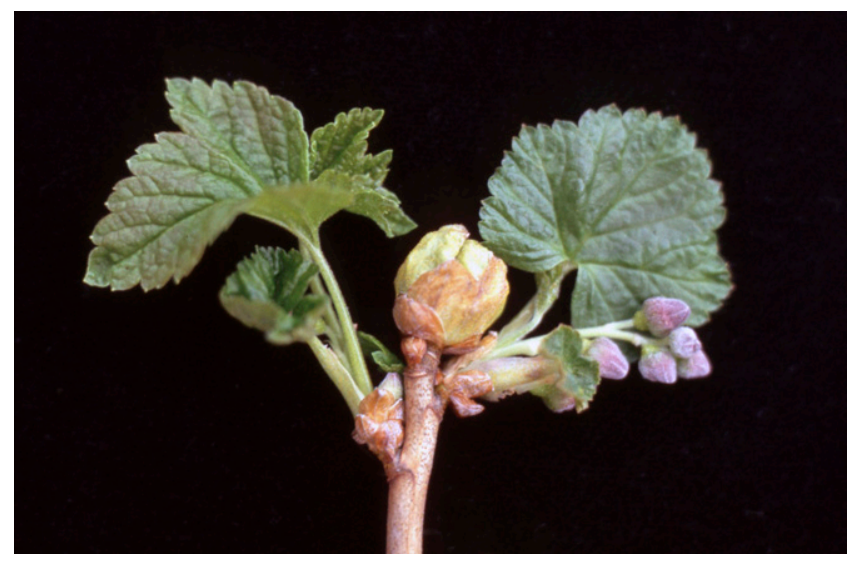

Fig. 9. Deformation of a bud in blackcurrant after infestation with the mite Cecidophyopsis ribis, Acari: Eriophyidae. 
Table 1. Viruses and phytoplasmas infecting Ribes, their vectors and primers for their detection

\begin{tabular}{|c|c|c|c|c|c|}
\hline $\begin{array}{l}\text { Virus name, genus, } \\
\text { abbreviation }\end{array}$ & Host $^{a}$ & Symptoms & $\begin{array}{c}\text { Vector/transmission } \\
\text { mode }^{b}\end{array}$ & Primers $5^{\prime}-3^{\prime}$ & Reference \\
\hline $\begin{array}{l}\text { Actinidia virus X, } \\
\text { Potexvirus, AVX }\end{array}$ & 1 & $\begin{array}{l}\text { Leaf chlorosis, } \\
\text { deformity }\end{array}$ & N/A & AAGTCCGCAACACCTACCTG & $\begin{array}{l}\text { James and Phelan } \\
2016\end{array}$ \\
\hline $\begin{array}{l}\text { Alfalfa mosaic virus, } \\
\text { Alfamovirus, AMV }\end{array}$ & 1,2 & $\begin{array}{l}\text { Interveinal white } \\
\text { mosaic }\end{array}$ & Aphids, nonpersistent & $\begin{array}{l}\text { GGACAGACGATAGCAGCCTT } \\
\text { CCATCATGAGTTCTTCACAAAAG } \\
\text { TCGTCACGTCATCAGTGAGAC }\end{array}$ & $\begin{array}{l}\text { Blouin et al. } 2013 \\
\text { Xu and Nie } 2006\end{array}$ \\
\hline $\begin{array}{l}\text { Arabis mosaic virus, } \\
\text { Nepovirus, ArMV }\end{array}$ & 1,2 & $\begin{array}{l}\text { Chlorotic mottling, } \\
\text { ringspot }\end{array}$ & $\begin{array}{l}\text { Xiphinema } \\
\text { diversicaudatum, } \\
\text { semipersistent, pollen, } \\
\text { seed }\end{array}$ & $\begin{array}{l}\text { TTGGCCCAGATATAGCGTAAAAAT } \\
\text { CAGCGGATTGGGAGTTCGT }\end{array}$ & $\begin{array}{l}\text { MacKenzie et al. } \\
1997\end{array}$ \\
\hline $\begin{array}{l}\text { Blackcurrant } \\
\text { waikavirus A, } \\
\text { Waikavirus, BCWVA }\end{array}$ & 7 & $\begin{array}{l}\text { Leaf malformation, } \\
\text { mosaic }\end{array}$ & N/A & $\begin{array}{l}\text { CCCAAGAACTTGCTGGATAAGA } \\
\text { CACCACCTAGCATAGGCATTAG }\end{array}$ & Ho et al. 2016 \\
\hline $\begin{array}{l}\text { Blackcurrant- } \\
\text { associated } \\
\text { rhabdovirus, } \\
\text { Nucleorhabdovirus, } \\
\text { BCaRV }\end{array}$ & 1 & $\begin{array}{l}\text { Early senescence leaf } \\
\text { leaving }\end{array}$ & N/A & $\begin{array}{l}\text { ACCGTCTGGACAATGTCCATACC } \\
\text { AGTAGGAGCACGCTTGACAGG }\end{array}$ & Wu et al. 2018 \\
\hline $\begin{array}{l}\text { Blackcurrant leaf } \\
\text { chlorosis associated } \\
\text { virus, Idaeovirus, } \\
\text { BCLCaV, syn. } \\
\text { Blackcurrant } \\
\text { idaeovirus }\end{array}$ & 1 & Chlorosis & Pollen & $\begin{array}{l}\text { AAGATAGTCTGGAAGAAGTTCGA } \\
\text { ACAATAGTCCAGATAGCGGAA }\end{array}$ & $\begin{array}{l}\text { Thekke-Veetil et al. } \\
2017\end{array}$ \\
\hline $\begin{array}{l}\text { Blackcurrant leafroll- } \\
\text { associated virus } 1 \text {, } \\
\text { Closterovirus, } \\
\text { BCLRaV-1 }\end{array}$ & 1,2 & $\begin{array}{l}\text { Downward leaf rolling, } \\
\text { interveinal reddening }\end{array}$ & Aphids, semipersistent & $\begin{array}{l}\text { TCCTACCAGACGCTTC } \\
\text { AGTGCGCTGTATTGTG }\end{array}$ & $\begin{array}{l}\text { Besse et al. } 2010 \\
\text { Koloniuk et al. } \\
2018\end{array}$ \\
\hline $\begin{array}{l}\text { Blackcurrant reversion } \\
\text { virus, Nepovirus, } \\
\text { BRV }\end{array}$ & 1,2 & $\begin{array}{l}\text { Abnormal leaves and } \\
\text { flowers }\end{array}$ & $\begin{array}{l}\text { Cecidophyopsis ribis, } \\
\text { semipersistent }\end{array}$ & $\begin{array}{l}\text { GTAATACGCTGGTGTCTC } \\
\text { GAAAGGACATTTCAGACTC }\end{array}$ & $\begin{array}{l}\text { Lemmetty et al. } \\
1997 \\
\text { Špak et al. } 2006\end{array}$ \\
\hline $\begin{array}{l}\text { Cherry leaf roll virus, } \\
\text { Nepovirus, CLRV }\end{array}$ & 2 & Pale green mottle & Pollen, seed & $\begin{array}{l}\text { GTCGGAAAGATTACGTAAAAGG } \\
\text { TGGCGACCGTGTAACGGCA }\end{array}$ & Werner et al. 1997 \\
\hline $\begin{array}{l}\text { Cucumber mosaic } \\
\text { virus, Cucumovirus, } \\
\text { CMV }\end{array}$ & 1,2 & $\begin{array}{l}\text { Mild mosaic, vein } \\
\text { yellowing }\end{array}$ & Aphids, nonpersistent & $\begin{array}{l}\text { YASYTTTDRGGTTCAATTCC } \\
\text { GACTGACCATTTTAGCCG }\end{array}$ & Choi et al. 1999 \\
\hline $\begin{array}{l}\text { Currant latent virus, } \\
\text { Cheravirus, CuLV }\end{array}$ & 1,2 & No symptoms & Cryptomyzus ribis & $\begin{array}{l}\text { ACCAGGAACAAATACCCATCTC } \\
\text { ATGTGCTGCCAAATTCAGAG }\end{array}$ & Petrzik et al. 2015 \\
\hline $\begin{array}{l}\text { Currant virus } \mathrm{A}, \\
\text { Capillovirus, } \mathrm{CuVA}\end{array}$ & 2 & No symptoms & N/A & $\begin{array}{l}\text { ATCTTCATCAAGTTATAGCATGCGAC } \\
\text { CAATTTCAATGACACGCAAATCAGG }\end{array}$ & Petrzik et al. 2016 \\
\hline $\begin{array}{l}\text { Gooseberry vein } \\
\text { banding associated } \\
\text { virus, Badnavirus, } \\
\text { GVBaV }\end{array}$ & $\begin{array}{c}1,2 \\
5\end{array}$ & Vein clearing & $\begin{array}{l}\text { Cryptomyzus ribis, } \\
\text { semipersistent, aphids }\end{array}$ & $\begin{array}{l}\text { GATTCGTCATCGCTTACGCCATC } \\
\text { GTCGGCTACTGCTCTAGATACTC }\end{array}$ & Petrzik et al. 2012 \\
\hline $\begin{array}{l}\text { Raspberry ringspot } \\
\text { virus, Nepovirus, } \\
\text { RpRSV }\end{array}$ & 2,6 & $\begin{array}{l}\text { Chlorotic line-pattern } \\
\text { "spoon leaf" }\end{array}$ & $\begin{array}{l}\text { Longidorus elongatus, } \\
\text { nematodes, semipersistent }\end{array}$ & $\begin{array}{l}\text { TGTGTCTGGTTTTGATGCT } \\
\text { GAGTGCGATAGGGGCTGTT }\end{array}$ & $\begin{array}{l}\text { Ochoa-Corona } \\
\text { et al. } 2006\end{array}$ \\
\hline $\begin{array}{l}\text { Ribes americanum } \\
\text { virus A, family } \\
\text { Tymovirales, RAVA }\end{array}$ & 7 & $\begin{array}{l}\text { Ragged leaf margins, } \\
\text { crinkled leaves }\end{array}$ & N/A & $\begin{array}{l}\text { TGAGACACAAGAACATGCTGTTTGA } \\
\text { TTCCACСССТACTCTCTTTGCCT }\end{array}$ & $\begin{array}{l}\text { Thekke-Veetil et al. } \\
2018\end{array}$ \\
\hline $\begin{array}{l}\text { Sowbane mosaic virus, } \\
\text { Sobemovirus, SoMV, } \\
\text { syn. Rubus chlorotic } \\
\text { mottle v. }\end{array}$ & 1 & Chlorotic mottle leaf & Pollen, seed & $\begin{array}{l}\text { AGTCCTGGGTGTCCATCTTG } \\
\text { AAGGCTTCTCAACGGTCTCA }\end{array}$ & $\begin{array}{l}\text { Besse et al. 2010; } \\
\text { McGavin and } \\
\text { MacFarlane } 2009\end{array}$ \\
\hline $\begin{array}{l}\text { Strawberry latent } \\
\text { ringspot virus, } \\
\text { Sadwavirus, SLRV }\end{array}$ & 1,2 & Bright yellowing & $\begin{array}{l}\text { Xiphinema } \\
\quad \text { diversicaudatum }\end{array}$ & $\begin{array}{l}\text { CCTCTCCAACCTGCTAGACT } \\
\text { AAGCGCATGAAGGTGTAACT }\end{array}$ & Martin et al. 2004 \\
\hline $\begin{array}{l}\text { Tobacco rattle virus, } \\
\text { Tobravirus, TRV }\end{array}$ & 1 & No symptoms & Nematodes, semipersistent & $\begin{array}{l}\text { CAGTCTATACACAGAAACAGA } \\
\text { GACGTGTGTACTCAAGGGTT }\end{array}$ & Robinson 1992 \\
\hline $\begin{array}{l}\text { Tomato black ring } \\
\text { virus, Nepovirus, } \\
\text { TBRV }\end{array}$ & 2 & Yellow line-pattern & $\begin{array}{l}\text { Longidorus elongates } \\
\text { Longidorus attenuates }\end{array}$ & $\begin{array}{l}\text { TCTGGITTTGCYTTRACRGT } \\
\text { CTTRTCACTVCCATCRGTAA } \\
\text { TGCATAGGCTCACTCCTTGGGA }\end{array}$ & $\begin{array}{l}\text { Wei and Clover } \\
2008\end{array}$ \\
\hline $\begin{array}{l}\text { Tomato ringspot virus, } \\
\text { Nepovirus, ToRSV }\end{array}$ & 2 & $\begin{array}{l}\text { Mosaic, pale green } \\
\text { mottle }\end{array}$ & $\begin{array}{l}\text { Xiphinema americanum, } \\
\text { nematodes, } \\
\text { semipersistent }\end{array}$ & $\begin{array}{l}\text { GACGAAGTTATCAATGGCAGC } \\
\text { TCCGTCCAATCACGCGAATA }\end{array}$ & Griesbach 1995 \\
\hline $\begin{array}{l}\text { Ca. Phytoplasma } \\
\text { asteris, 16SrI-C, } \\
\text { 16SrI-B }\end{array}$ & $\begin{array}{l}1,2 \\
1,2\end{array}$ & $\begin{array}{l}\text { Shoot twisting, full } \\
\text { blossom }\end{array}$ & N/A & $\begin{array}{l}\text { GAAACGACTGCTAAGACTGG } \\
\text { TGACGGGCGGTGTGTACAAACCCCG }\end{array}$ & Špak et al. 2009 \\
\hline $\begin{array}{l}\text { Ca. Phytoplasma mali, } \\
\text { 16SrX-A }\end{array}$ & 1,2 & $\begin{array}{l}\text { Shoot twisting, full } \\
\text { blossom }\end{array}$ & N/A & & \\
\hline $\begin{array}{l}\mathrm{Ca} \text {. Phytoplasma } \\
\text { prunorum, } 16 \mathrm{SrX}-\mathrm{B}\end{array}$ & 1,2 & & & & \\
\hline $\begin{array}{l}\text { Ca. Phytoplasma pyri, } \\
16 \mathrm{SrX}-\mathrm{C}\end{array}$ & 1,2 & Full blossom & & & \\
\hline
\end{tabular}


series of cultivars resistant to the mite. The success is such that 'Ben' is planted in over $95 \%$ of the UK growing areas and around $50 \%$ in the rest of the world. Control of GVBaV and other aphid-transmitted viruses depends on planting virus-tested plants, roguing infected material, and controlling aphids (Jones 2002). However, this is more challenging with increasing pressure to abandon potent insecticide formulations because of concern of their impact on the environment and food safety. Mitchell et al. (2011) reviewed 12 key pests of currant and gooseberry crops in Northern Europe, including aphid vectors such as the redcurrant blister aphid (Cryptomyzus ribis), the currant-sowthistle aphid (Hyperomyzus lactucae), and the European gooseberry aphid (Aphis grossulariae), with emphasis on their biology and management options. They concluded that use of predators for aphid control is largely unsuccessful.

The use of clean propagation material is the basis for control of $R i$ bes virus and virus-like diseases (Martin and Tzanetakis 2015), but this has become a challenging task given the number of newly discovered viruses. Given that many Ribes viruses appear asymptomatic in single infections, it is advisable to develop certification schemes around the world for Ribes in which G1 plants are tested for all viruses and grafttransmissible agents (possibly through HTS) and G2-G4 are tested for the viruses that are most prevalent in the locality of the nursery (Gergerich et al. 2015). Testing could be done using the 'block' approach where a defined number of plants are tested based on the probability of identifying pathogens (hypergeometric distribution). For example, G3 plants could be tested for the most prevalent viruses (e.g., BRV, $\mathrm{GVBaV}$, and $\mathrm{CMV}$ ) to detect them at $1 \%$ infection incidence with 99\% confidence, whereas G4 plants, given the much higher number of plants, would be tested at $5 \%$ infection incidence with $95 \%$ confidence. This does not eliminate viruses from the nursery system but minimizes the possibility of massive dissemination of infected, asymptomatic material that could potentially start an epidemic once planted in commercial fields (Gergerich et al. 2015).

Mechanical inoculation to test plants, graft transmission, and ELISA are EPPO-recommended testing methods for graft transmissible pathogens in Ribes (Anonymous 2008; Anonymous 2017). Recent studies employing HTS to study the Ribes virome revealed that visual scouting for virus-like symptoms could serve only as a preliminary indication of a virus infection (Al Rwahnih et al. 2015). Detection of latent infections or sporadic symptoms are not reliable or sufficient for the deployment of quarantine and protective measures. Based on our long-term observations and experiments, and with respect to the lack of available antibodies against the newly identified viruses, we conclude that RT-PCR is currently the most expedient, reliable, and sensitive method for detecting viruses and phytoplasmas in Ribes. Table 1 summarizes suitable primers for the detection of Ribes-infecting viruses. It should be noted that test reliability cannot be fully guaranteed because the variability of virus genomes has not been studied for the majority of viruses infecting Rubus. Nevertheless, we recommend primers that were proven in testing of Ribes or other berry species (MacFarlane et al. 2015). The cited references can guide potential users to additional or more specific primers for individual viruses and serve as a tool enabling rapid detection of pathogens by RT-PCR for their subsequent elimination through tissue cultures and other control measures.

\section{Summary}

Ribes spp. can be infected by more than 20 virus species and four $\mathrm{Ca}$. Phytoplasma species, with more likely to be described in the future. It is difficult to predict the number of systemic pathogens infecting these crops in the future given the constant movement of plant products and pathogens across the globe. However, it is important to implement measures that minimize spread of pathogens and vectors. There are several excellent reviews tackling these issues, including recent APS compendia on berry crops (Martin et al. 2017; Polashock et al. 2017).

It is evident that the single most important part of the health status of any clonally propagated crop is the planting material. HTS has provided an exceptional tool for the diagnosis of known viruses and the discovery of new ones. This technology is not universally accepted as a replacement for current standards. However, as more studies like those of Al Rwahnih et al. (2015) and Rott et al. (2017) compare the efficiencies of HTS to standard methods, we predict that HTS will be used at least at the G1 plant stage to verify their health status. As the cost of the technology declines and bioinformatics analysis becomes readily available to the majority of researchers and regulators, we foresee that HTS will become the dominant diagnostics tool for assaying the health status of Ribes plants (Massart et al. 2019).

Given the lack of in-depth reviews on Ribes systemic pathogens since that of Converse (1987) some 34 years ago, we feel that this review can be a useful tool for Ribes propagators, breeders, and growers to improve their orientation to newly described viruses and protection against viruses in general.

\section{Literature Cited}

Adams, A. N., and Posnette, A. F. 1987. Gooseberry vein banding. Page 129 in: Virus Disease of Small Fruits. R. H. Converse, ed. United States Department of Agriculture, Washington, DC.

Adams, A. N., and Thresh, J. M. 1987a. Detection of virus and viruslike diseases in Ribes. Page 127 in: Virus Disease of Small Fruits. R. H. Converse, ed. United States Department of Agriculture, Washington, DC.

Adams, A. N., and Thresh, J. M. 1987b. Green mottle of blackcurrant. Page 136 in: Virus Disease of Small Fruits. R. H. Converse, ed. United States Department of Agriculture, Washington, DC.

Adams, A. N., and Thresh, J. M. 1987c. Reversion of blackcurrant. Pages 133-136 in: Virus Disease of Small Fruits. R. H. Converse, ed. United States Department of Agriculture, Washington, DC.

Al Rwahnih, M., Daubert, S., Golino, D., Islas, C., and Rowhani, A. 2015 Comparison of next-generation sequencing versus biological indexing for the optimal detection of viral pathogens in grapevine. Phytopathology 105: 758-763.

Anonymous. 2008. Certification scheme for Ribes. EPPO Bull. 38:14-18.

Anonymous. 2017. EU certification scheme fruit plants. Explanatory guide to blackcurrants, red currants, white currants and gooseberries (Ribes). Animal and Plant Health Agency, Addlestone, UK. https://assets.publishing.service.gov.uk/ government/uploads/system/uploads/attachment_data/file/675606/eu-certificationscheme-ribes.pdf

Barney, D. L., and Hummer, K. E. 2005. Currants, Gooseberries, and Jostaberries A Guide for Growers, Marketers, and Researchers in North America. The Haworth Press Inc., Binghamton, NY.

Besse, S., Gugerli, P., Ramel, M. E., and Balmelli, C. 2010. Characterisation of mixed virus infections in Ribes species in Switzerland. Pages 214-219 in 21st International Conference on Virus and other Graft Transmissible Diseases of Fruit Crops, Neustadt, Germany.

Blouin, A. G., Pearson, M. N., Chavan, R. R., Woo, E. N. Y., Lebas, B. S. M., Veerakone, S., Ratti, C., Biccheri, R., MacDiarmid, R. M., and Cohen, D. 2013. Viruses of kiwifruit (Actinidia species). J. Plant Pathol. 95:221-235.

Bremer, K. 1983. Viral diseases occurring on Ribes species in Finland. Ann. Agric. Fenn. 22:104-109.

Brennan, R., Jorgensen, L., Gordon, S., Loades, K., Hackett, C., and Russell, J. 2008. The development of a PCR-based marker linked to resistance to the blackcurrant gall mite (Cecidophyopsis ribis Acari: Eriophyidae). Theor. Appl. Genet. 118:205-211.

Brennan, R., Jorgensen, L., Hackett, C., Woodhead, M., Gordon, S., and Russell, J. 2007. The development of a genetic linkage map of blackcurrant (Ribes nigrum L.) and the identification of regions associated with key fruit quality and agronomic traits. Euphytica 161:19-34.

Brown, D. J. F., Robertson, W. M., and Trudgill, D. L. 1995. Transmission of viruses by plant nematodes. Annu. Rev. Phytopathol. 33:223-249.

Brown, D. J. F., Trudgill, D. L., and Robertson, W. M. 1996. Nepoviruses: transmission by nematodes. Pages 187-209 in: The Plant Viruses. B. D. Harrison and A. F. Murant, eds. Springer US, Boston, MA.

Choi, S. K., Choi, J. K., Park, W. M., and Ryu, K. H. 1999. RT-PCR detection and identification of three species of cucumoviruses with a genus-specific single pair of primers. J. Virol. Methods 83:67-73.

Converse, R. H., ed. 1987. Virus Disease of Small Fruits. United States Department of Agriculture, Washington, DC.

Dolan, A., MacFarlane, S., McGavin, W., Brennan, R., and McNicol, J. 2011 Blackcurrant reversion virus: Validation of an improved diagnostic test, accelerating testing in breeding and certification of blackcurrants. J. Berry Res. 1:201-208.

EFSA PLH Panel (EFSA Plant Health Panel), Bragard, C., Dehnen-Schmutz, K., Gonthier, P., Jacques, M.-A., Jaques Miret, J. A., Justesen, A. F., MacLeod, A., Magnusson, C. S., Milonas, P., Navas-Cortes, J. A., Parnell, S., Potting, R., Reignault, P. L., Thulke, H.-H., Van der Werf, W., Vicent Civera, A., Yuen, J, Zappala, L., Candresse, T., Chatzivassiliou, E., Winter, S., Chiumenti, M., Di Serio, F., Kaluski, T., Minafra, A., Rubino, L. 2019. List of non-EU viruses and viroids of Cydonia Mill., Fragaria L., Malus Mill., Prunus L., Pyrus L., Ribes L., Rubus L. and Vitis L. EFSA J. 17:5501. 
FAOSTAT. 2020. FAOSTAT data. http://www.fao.org/faostat/en/\#data/QC. Accessed March 4, 2020.

Gergerich, R. C., Welliver, R., Gettys, S., Osterbauer, N. K., Kamenidou, S., Martin, R. R., Golino, D., Eastwell, K., Fuchs, M., Vidalakis, G., and Tzanetakis, I. E. 2015. Safeguarding fruit crops in the age of agricultural globalization. Plant Dis. 99:176-187.

Griesbach, J. A. 1995. Detection of Tomato ringspot virus by polymerase chain reaction. Plant Dis. 79:1054-1056.

Ho, T., Postman, J. D., and Tzanetakis, I. E. 2016. Discovery, characterization and detection of five new virus species in Ribes. Pages 8-10 in: PSJ Plant Virus Disease Workshop Report No.12 (Special Edition); International Conference on Virus and other Graft Transmissible Diseases of Fruit Crops, Morioka, Japan

Ho, T., and Tzanetakis, I. E. 2014. Development of a virus detection and discovery pipeline using next generation sequencing. Virology 471-473: 54-60.

International Blackcurrant Association. 2019. Global blackcurrant production, historical data. https://www.blackcurrant-iba.com/wp-content/uploads/2019/ 10/Global-BC-Production-2009-2018.pdf

James, D., and Phelan, J. 2016. Complete genome sequence of a strain of Actinidia virus $\mathrm{X}$ detected in Ribes nigrum cv. Baldwin showing unusual symptoms. Arch. Virol. 161:507-511.
James, D., and Phelan, J. 2017. Complete genome sequence and analysis of blackcurrant leaf chlorosis associated virus, a new member of the genus Idaeovirus. Arch. Virol. 162:1705-1709.

Jones, A. T. 2002. Important virus diseases of Ribes, their diagnosis, detection and control. Acta Hortic. 585:279-285.

Jones, A. T., Brown, D. J. F., McGavin, W. J., Rüdel, M., and Altmayer, B. 1994 Properties of an unusual isolate of raspberry ringspot virus from grapevine in Germany and evidence for its possible transmission by Paralongidorus maximus. Ann. Appl. Biol. 124:283-300.

Jones, A. T., and McGavin, W. J. 1996. A damaging outbreak of arabis mosaic nepovirus in blackcurrant, the occurrence of other nepoviruses in Ribes species, and the demonstration that alfalfa mosaic virus is the cause of interveinal white mosaic in blackcurrant. Ann. Appl. Biol. 129:47-55.

Koloniuk, I., Thekke-Veetil, T., Reynard, J.-S., Mavrič Pleško, I., Přibylová, J., Brodard, J., et al. 2018. Molecular characterization of divergent Closterovirus isolates infecting Ribes species. Viruses 10:369.

Lebas, B. S. M., Veerakone, S., Liefting, L. W., Tang, J., Perez-Egusquiza, Z., von Bargen, S., and Ward, L. 2016. Comparison of diagnostic techniques for the detection and differentiation of Cherry leaf roll virus strains for quarantine purposes. J. Virol. Methods 234:142-151.

Lemmetty, A., Latvala, S., Jones, A. T., Susi, P., McGavin, W. J., and Lehto, K 1997. Purification and properties of a new virus from blackcurrant, its affinities
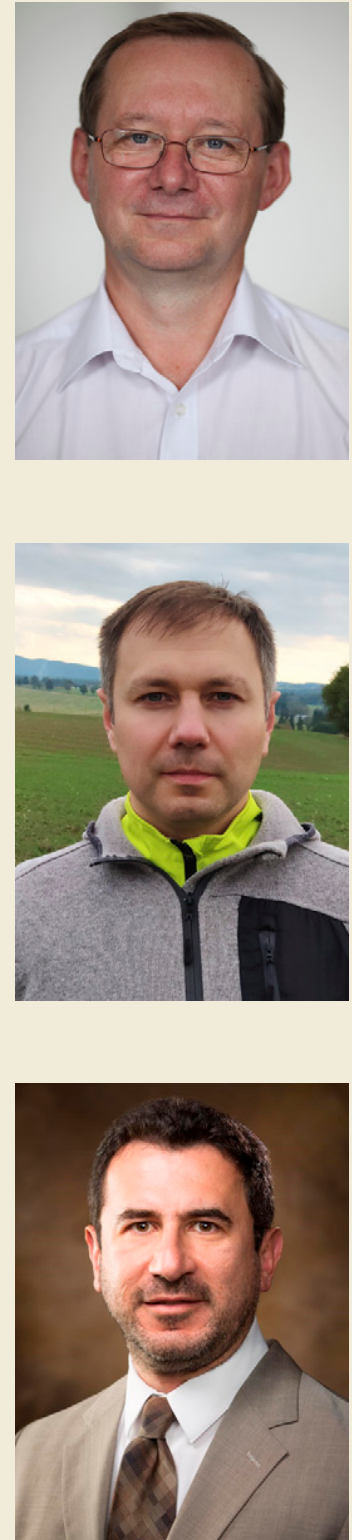

Dr. Josef Špak is director of the Institute of Plant Molecular Biology at the Biology Centre (IPMB BC) of the Czech Academy of Sciences (CAS) and a professor at the Faculty of Science, University of South Bohemia in České Budějovice, Czech Republic. He received an Ing. degree in agronomy at the Czech University of Agriculture in Prague in 1982 and a Ph.D. in phytopathology and plant protection at the Institute of Experimental Botany CAS in 1987 for research on brassica viruses and their transmission by vectors. Since 1988 he has built up the Plant Virology Department at the IPMB BC with research programs focused on small fruit and fruit-tree viruses and phytoplasmas and their serological and molecular diagnosis. He has received numerous national and international grants and has long-term collaboration with the Research and Breeding Institute of Pomology and the Czech State Phytosanitary Administration. He has authored or co-authored over 90 peer-reviewed articles in scientific journals. $\mathrm{He}$ acts as a member of several editorial boards of international scientific journals, as an expert for the Czech Ministry of Agriculture, and referee of national and international grant agencies.

Dr. Igor Koloniuk is a plant virologist and the head of the Department of Plant Virology, Biology Centre CAS (Czech Republic). He received his B.S. and M.S. degrees in microbiology and virology at the National State University in Kyiv (Ukraine). In 2010, he was awarded a Ph.D. for his work studying radish mosaic virus and turnip ringspot virus from the University of South Bohemia (Czech Republic). His current research focuses primarily on plant viruses and their intra- and interhost variability. Dr. Koloniuk has published more than 40 research papers.

Dr. loannis Tzanetakis has a B.S./M.S. in soil science and a Ph.D. in molecular and cellular biology. He is currently a professor of plant virology, working primarily on the epidemiology of berry and ornamental viruses. He reviews for more than 60 scientific publications and is a member of the editorial boards of several plant pathology and virology journals. He is also a member of several national and international organizations and societies including the American Phytopathological Society, the National Clean Plant Network, the International Committee on Taxonomy of Viruses, and the International Council for the Study of Virus and other Graft Transmissible Diseases of Fruit Crops among others. 
with nepoviruses, and its close association with blackcurrant reversion disease. Phytopathology 87:404-413.

Lemmetty, A., and Lehto, K. 1999. Successful back-inoculation confirms the role of blackcurrant reversion associated virus as the causal agent of reversion disease. Eur. J. Plant Pathol. 105:297-301.

MacFarlane, S., McGavin, W., and Tzanetakis, I. 2015. Virus testing by PCR and RT-PCR amplification in berry fruit. Methods Mol. Biol. 1302:227-248.

MacKenzie, D. J., McLean, M. A., Mukerji, S., and Green, M. 1997. Improved RNA extraction from woody plants for the detection of viral pathogens by reverse transcription-polymerase chain reaction. Plant Dis. 81:222-226.

Martin, R. R., Ellis, M. A., Williamson, B., and Williams, R. N., eds. 2017. Compendium of Raspberry and Blackberry Diseases and Pests, 2nd Ed. APS Press, St. Paul, MN.

Martin, R. R., and Tzanetakis, I. E. 2015. Control of virus diseases of berry crops. Adv. Virus Res. 91:271-309.

Martin, R. R., Tzanetakis, I. E., Barnes, J. E., and Elmhirst, J. F. 2004. First report of Strawberry latent ringspot virus in strawberry in the United States and Canada. Plant Dis. 88:575.

Massart, S., Chiumenti, M., De Jonghe, K., Glover, R., Haegeman, A., Koloniuk, I., et al. 2019. Virus detection by high-throughput sequencing of small RNAs: large-scale performance testing of sequence analysis strategies. Phytopathology 109:488-497.

McGavin, W. J., and MacFarlane, S. A. 2009. Rubus chlorotic mottle virus, a new sobemovirus infecting raspberry and bramble. Virus Res. 139:10-13.

Mitchell, C., Brennan, R. M., Cross, J. V., and Johnson, S. N. 2011. Arthropod pests of currant and gooseberry crops in the U.K.: their biology, management and future prospects. Agric. For. Entomol. 13:221-237.

Musil, M., Rakus, D., and Mucha, V. 1979. Some properties of cucumber mosaic virus isolated in Czechoslovakia from Ribes rubrum L. Biologia. 34:321-327.

Nielsen, M. R., Laursen, M. S., Jonassen, M. S., Nielsen, K., and Jørgensen, R. N. 2013. Gall mite inspection on dormant blackcurrant buds using machine vision. Pages 517-524 in: Precision agriculture. J. V. Stafford, ed. Wageningen Academic Publishers, Wageningen, the Netherlands.

Ochoa-Corona, F. M., Lebas, B. S. M., Tang, J. Z., Bootten, T. J., Stewart, F. J., Elliott, D. R., and Alexander, B. J. R. 2006. RT-PCR detection and strain typing of Raspberry ringspot virus. Page 137 in: Proceedings of the XXth International Symposium on Virus and Virus-like Diseases of Temperate Fruit Crops \& XIth International Symposium on Small Fruit Virus Diseases, Antalya, Turkey.

Pearson, M. N., Cohen, D., Chavan, R., and Blouin, A. 2011. Actinidia is a natural host to a wide range of plant viruses. Acta Hortic. 913:467-471.

Pedersen, H. L., Paaske, K., Sorensen, L., and Kampuss, K. 2006. Hot water dipping of blackcurrant cuttings controlling gall mites and increase plant growth. Page 23 in: Abstract book: Berry plant quality and sustainable production. COST 863 JM WG 2\&3. Zagreb, Croatia.

Petrzik, K., Přibylová, J., Koloniuk, I., and Špak, J. 2016. Molecular characterization of a novel capillovirus from red currant. Arch. Virol. 161:1083-1086.

Petrzik, K., Přibylová, J., and Špak, J. 2012. Molecular analysis of gooseberry vein banding associated virus. Acta Virol. 56:119-124.

Petrzik, K., Přibylová, J., Špak, J., and Havelka, J. 2015. Partial genome sequence of currant latent virus, a new chera-like virus related to Apple latent spherical virus. J. Gen. Plant Pathol. 81:142-145.

Ploeg, A. T., Brown, D. J. F., and Robinson, D. J. 1992. The association between species of Trichodorus and Paratrichodorus vector nematodes and serotypes of tobacco rattle tobravirus. Ann. Appl. Biol. 121:619-630.

Pluta, S. 2012. New challenges in the Ribes breeding and production. Acta Hortic. 946:27-35

Pluta, S., and Zurawicz, E. 1999. Influence of graft-inoculation methods on the spread of two forms of reversion virus in blackcurrant (Ribes nigrum L.) plants. Acta Hortic. 505:167-172.
Polashock, J., Caruso, F., Averill, A., and Schilder, A., eds. 2017. Compendium of Blueberry, Cranberry, and Lingonberry Diseases and Pests, 2nd Ed. APS Press, St. Paul, MN.

Rakús, D. 1971. Nová choroba červených ribezlí (A new disease of red currant). Biologia. 26:355-358.

Rakús, D., Králík, O., and Brčák, J. 1974. Mycoplazma v Ribes houghtonianum Jancz. nakazené „plnokvetosti“ (Mycoplasma-like organism in Ribes houghtonianum Jancz, infected with a Yellows disease). Sbor. ÚVTI -. Ochr. Rostl. 10:307-309.

Ritzema Bos, G. 1904. Eenige misvormingen of monstrositeiten (Some malformations and monstrosities). Tijdscrift over Planzenziekten. 10:135-144.

Roberts, I. M., and Jones, A. T. 1997. Rhabdovirus-like and closterovirus-like particles in ultrathin sections of Ribes species with symptoms of blackcurrant reversion and gooseberry veinbanding diseases. Ann. Appl. Biol. 130:77-89.

Robinson, D. J. 1992. Detection of tobacco rattle virus by reverse transcription and polymerase chain reaction. J. Virol. Methods 40:57-66.

Rott, M., Xiang, Y., Boyes, I., Belton, M., Saeed, H., Kesanakurti, P., et al. 2017 Application of next generation sequencing for diagnostic testing of tree fruit viruses and viroids. Plant Dis. 101:1489-1499.

Špak, J., Kubelková, D., Přibylová, J., Špaková, V., and Petrzik, K. 2009. Elucidation of the roles of Blackcurrant reversion virus and phytoplasma in the etiology of full blossom disease in currants. Plant Dis. 93:832-838.

Špak, J., Navrátil, M., Karešová, R., Přibylová, J., Válová, P., Kučerová, J., et al. 2006. Occurrence, symptom variation and yield loss caused by full blossom disease in red and white currants in the Czech Republic. Crop Prot. 25:446-453.

Thekke-Veetil, T., Ho, T., Postman, J., Martin, R., and Tzanetakis, I. 2018. A virus in American blackcurrant (Ribes americanum) with distinct genome features reshapes classification in the Tymovirales. Viruses 10:406.

Thekke-Veetil, T., Ho, T., Postman, J. D., and Tzanetakis, I. E. 2017. Characterization and detection of a novel idaeovirus infecting blackcurrant. Eur. J. Plant Pathol. 149:751-757.

Thekke-Veetil, T., Ho, T., Postman, J. D., and Tzanetakis, I. E. 2020. Comparative analysis of a new blackcurrant waikavirus with other members of the genus. Eur. J. Plant Pathol. 157:59-64.

Tremaine, J. G., and Hamilton, R. I. 1983. Southern bean mosaic virus. CMI/AAB Descriptions of Plant Viruses no. 274. Commonwealth Mycological Institute, Kew, Surrey, and Association of Applied Biologists, Wellesbourne, Warwick, England.

Valasevich, N., and Kolbanova, E. 2010. Occurrence of small fruit viruses in Belarus. Pages 201-213 in: 21st International Conference on Virus and Other Graft Transmissible Diseases of Fruit Crops, Neustadt, Germany.

van der Meer, F. A. 1987. Leaf pattern of red currant. Pages 150-152 in: Virus Disease of Small Fruits. R. H. Converse, ed. United States Department of Agriculture, Washington, DC.

Wei, T., and Clover, G. 2008. Use of primers with $5^{\prime}$ non-complementary sequences in RT-PCR for the detection of nepovirus subgroups A and B. J. Virol. Methods 153:16-21.

Werner, R., Mühlbach, H.-P., and Büttner, C. 1997. Detection of cherry leaf roll nepovirus (CLRV) in birch, beech and petunia by immuno-capture RT-PCR using a conserved primer pair. Eur. J. Plant Pathol. 27:309-318.

Wood, G. A., and Langford, G. I. 1998. Further investigations of the blackcurrant reversion disease in New Zealand. N. Z. J. Crop Hortic. Sci. 26:205-214.

Wu, L. P., Yang, T., Liu, H. W., Postman, J., and Li, R. 2018. Molecular characterization of a novel rhabdovirus infecting blackcurrant identified by high-throughput sequencing. Arch. Virol. 163:1363-1366.

$\mathrm{Xu}, \mathrm{H}$., and Nie, J. 2006. Identification, characterization, and molecular detection of Alfalfa mosaic virus in potato. Phytopathology 96:1237-1242.

Zheng, L., Wu, L., Postman, J., Liu, H., and Li, R. 2018. Molecular characterization and detection of a new closterovirus identified from blackcurrant by high-throughput sequencing. Virus Genes 54:828-832. 